\title{
OMNIBUS LAW SEBAGAI TEKNIK PEMBENTUKAN UNDANG-UNDANG: PELUANG ADOPSI DAN TANTANGANNYA DALAM SISTEM PERUNDANG-UNDANGAN INDONESIA
}

\author{
(Omnibus Law as a Technique For Formation Of Law: Opportunities For Adoption And Its Challenges \\ In Indonesia's Legislation System)
}

\author{
Bayu Dwi Anggono \\ Fakultas Hukum Universitas Jember \\ Jalan Kalimantan No. 37, Kampus Tegalboto, Jember, Jawa Timur \\ e-mail: bayu_fhunej@yahoo.co.id
}

Naskah diterima: 10 Februari 2020; revisi: 3 April 2020; disetujui: 6 April 2020

\begin{abstract}
Abstrak
Usulan Presiden Joko Widodo untuk menerbitkan Omnibus Law menuai reaksi publik. Hal ini karena Indonesia menganut sistem hukum civil law, sementara omnibus law dari sistem hukum common law, serta setiap undang-undang memiliki landasan filosofis, yuridis, dan sosiologis berbeda sehingga menyulitkan memastikannya tetap ada dalam omnibus law. Rumusan permasalahan penulisan ini adalah bagaimana konsepsi, manfaat dan kelemahan pembentukan UndangUndang melalui model omnibus law, kemudian bagaimana peluang dan tantangan omnibus law untuk dapat diadopsi dalam sistem perundang-undangan Indonesia. Penulisan ini menggunakan metode penelitian yuridis normatif, dengan pendekatan perundang-undangan dan konsep, yang juga mengkaji studi dokumen. Manfaat omnibus law bagi pembentuk undang-undang akan mudah mencapai kesepakatan dan menghindarkan dari kebuntuan politik, menghemat waktu dan mempersingkat proses legislasi, pembentukan Undang-Undang menjadi lebih efisien, dan meningkatkan produktivitas dalam pembentukan Undang-Undang. Kelemahan omnibus law adalah pragmatis dan kurang demokratis, membatasi ruang partisipasi maupun disusun tidak sistematis dan kurang hati-hati. Peluang diadopsinya teknik omnibus law secara permanen dalam sistem perundang-undangan di Indonesia akan sangat tergantung dari keberhasilan dan manfaat Undang-Undang omnibus law yang dihasilkan. Sejumlah persyaratan perlu dipenuhi dalam penggunaan omnibus law di Indonesia yakni pemenuhan azas keterbukaan, kehati- hatian, dan partisipasi masyarakat serta sebaiknya tidak dilakukan untuk kebijakan yang mengandung skala besar utamanya berkaitan dengan HAM
\end{abstract}

Kata Kunci: omnibus law, adopsi, tantangan

\begin{abstract}
President Joko Widodo's proposal to publish Omnibus Law drew public reaction. Different legal system in which each law has a different philosophical, juridical, and sociological basis, making it difficult to ensure that it remains in the omnibus law. This writing will focus on problemas about how the conceptions, benefits and weaknesses of the formation of the Law through the omnibus law model, then how are the opportunities and challenges of the omnibus law to be adopted in the Indonesian legislative system. This writing uses a normative juridical research method, with legislation and concept approaches, which also studies the study of documents. For legislators, the omnibus law will easily reach agreement and avoid political deadlock, save time and shorten the legislative process, more efficient, and increase productivity. On the other side, the omnibus law is pragmatic and less democratic, limits the space for participation and is arranged in a systematic and inaccurate manner. The opportunity for permanent adoption of the omnibus law technique will depend on the success and benefits in establishing omnibus law. A number of requirements need to be met, namely fulfillment of the principles of openness, prudence, and public participation and should not be done for large-scale policies, especially related to human rights.
\end{abstract}

Keywords: omnibus law, adoption, challenges 


\section{A. Pendahuluan}

Menjelang akhir tahun 2019 omnibus law secara cepat menjadi diskursus tidak saja di lingkungan akademisi hukum melainkan juga di jajaran pemerintahan dan dunia usaha. Saat Sidang Paripurna Majelis Permusyawaratan Rakyat (MPR) dalam rangka pelantikan Presiden dan Wakil Presiden periode 2019 - 2024 tanggal 20 Oktober 2019 salah satu materi pidato yang disampaikan oleh Presiden Joko Widodo adalah rencana mengajak Dewan Perwakilan Rakyat (DPR) untuk menerbitkan satu Undang-Undang (UU) yang sekaligus merevisi beberapa UU, bahkan puluhan UU yang disebut sebagai omnibus law. ${ }^{1}$

Omnibus law yang dimaksud dalam pidato Presiden adalah UU Cipta Lapangan Kerja dan UU Pemberdayaan Usaha Mikro Kecil Menengah (UMKM). Tujuan dibuatnya omnibus law menurut Presiden adalah untuk mengatasi segala bentuk kendala regulasi yang tengah dialami Indonesia sehingga regulasi harus disederhanakan, dipotong dan dipangkas jumlahnya. ${ }^{2}$

Apa yang disampaikan oleh Presiden Joko Widodo soal penyederhanaan regulasi sebenarnya sudah sering diucapkan pada masa periode pertama jabatannya 2014 - 2019. Tercatat pada Maret 2016 saat memberikan arahan di Rapat Kerja Pemerintah Presiden menyatakan ada 2 hal prioritas yang fokus ingin dikerjakan dalam lima tahun ke depan yaitu deregulasi dan percepatan pembangunan infrastruktur. ${ }^{3}$ Dalam kesempatan itu, Presiden juga menyoroti keberadaan 42 Ribu peraturan di tingkat pusat dan 3 Ribu Peraturan Daerah yang bisa menghambat pembangunan. ${ }^{4}$

Berikutnya pada Januari 2017 Presiden meluncurkan kebijakan reformasi hukum tahap II yang salah satunya penataan regulasi. $^{5} \quad$ Melalui penataan regulasi Presiden menekankan bahwa Pemerintah akan mengevaluasi sejumlah regulasi yang tidak sinkron dan yang dapat menimbulkan multitafsir. Hal ini penting mengingat regulasi yang multitafsir dapat berdampak pada lemahnya daya saing Indonesia di kancah global. ${ }^{6}$

Kuatnya kemauan politik yang telah ditunjukkan oleh Presiden Joko Widodo telah ditindaklanjuti oleh beberapa kementerian terkait salah satunya adalah Kementerian Hukum dan HakAsasi Manusia yang mempunyai tugas dan fungsi menyelenggarakan urusan pemerintahan di bidang perundang-

\footnotetext{
Kompas.Com. "Naskah Lengkap Pidato Presiden JokoWidodo dalam Pelantikan Periode 2019-2024", https://nasional.kompas.com/jeo/naskah-lengkap-pidato-presiden-joko-widodo-dalam-pelantikanperiode-2019-2024, diakses 18 Januari 2020. Sidang Paripurna MPR dalam rangka pelantikan presiden dan wakil presiden adalah pelaksanaan ketentuan Pasal 9 Undang-Undang Dasar Negara Republik Indonesia Tahun 1945 (UUD 1945) yang menyebutkan: Sebelum memangku jabatannya, Presiden dan Wakil Presiden bersumpah menurut agama, atau berjanji dengan sungguh-sungguh di hadapan Majelis Permusyawaratan Rakyat atau Dewan Perwakilan Rakyat.

3 Sekretariat Kabinet.Go.Id, "Buat Pemerintah Tidak Leluasa, Presiden Jokowi Minta Aturan-Aturan Disederhanakan", https://setkab.go.id/buat-pemerintah-tidak-leluasa-presiden-jokowi-minta-aturan-aturandisederhanakan/, diakses 18 Januari 2020

Ibid.

5 Hukumonline.Com, "Ini 3 Agenda Paket Reformasi Hukum Jilid II", https://www.hukumonline.com/berita/baca/ lt587e0fdb06ea8/ini-3-agenda-paket-reformasi-hukum-jilid-ii/, diakses 18 Januari 2020
}

2 Ibid.

6 Ibid. 
undangan. ${ }^{7}$ Beberapa kebijakan telah diambil mulai dari memperketat usulan regulasi baru, memperkuat harmonisasi rancangan regulasi termasuk Peraturan Menteri/Lembaga, penelaan kembali rancangan regulasi sebelum diundangkan, melakukan evaluasi atas keberlakuan regulasi dan melakukan mediasi dalam hal terjadi sengketa atau konflik antar regulasi. ${ }^{8}$

Kementerian teknis seperti Kementerian Energi dan Sumber Daya Mineral (ESDM) telah memangkas sejumlah regulasi yang menjadi kewenangannya. ${ }^{9}$ Kementerian ESDM sebagaimana pengumuman pada Maret 2018 menyatakan telah mencabut 90 regulasi dan 96 sertifikasi, rekomendasi serta perizinan.

Pada perkembangannya apa yang dipidatokan Presiden mulai terlaksana pada 30 Januari 2020 saat Menteri Keuangan Sri Mulyani yang mewakili Presiden menyerahkan Surat Presiden (Surpres) terkait omnibus law Rancangan Undang-undang (RUU) Perpajakan ke Dewan Perwakilan Rakyat (DPR). Hal ini disusul pada 12 Februari 2020 Menteri Koordinator Perekonomian Airlangga Hartarto menyerahkan Supres dan omnibus law RUU Cipta Kerja ke DPR. ${ }^{10}$ Khusus mengenai pemberdayaan dan pengembangan UMKM pada akhirnya tidak menjadi RUU tersendiri melainkan masuk menjadi bagian dari RUU Cipta Kerja. ${ }^{11}$

Hingga berakhirnya periode pertama pemerintahan Presiden Joko Widodo berbagai upaya penataan regulasi belum mencapai hasil yang diharapkan. Pusat Studi Hukum dan Kebijakan (PSHK) menyatakan terdapat sejumlah pekerjaan rumah yang harus diselesaikan periode berikutnya mulai jumlah regulasi/peraturan yang terus menggunung, substansinya tumpang tindih, menurunnya tingkat partisipasi publik, hingga janji reformasi kelembagaan untuk mengatasi penataan regulasi tak kunjung terealisasi. ${ }^{12}$ Penelitian PSHK menunjukkan kurun waktu Oktober 2014 sampai Oktober 2018 ada total 8.945 regulasi yang dibentuk di tingkat

Pasal 3 Peraturan Presiden Nomor 44 Tahun 2015 Tentang Kementerian Hukum Dan Hak Asasi Manusia.

8 Lihat Peraturan Menteri Hukum Dan Hak Asasi Manusia Nomor 22 Tahun 2018 Tentang Pengharmonisasian Rancangan Peraturan Perundang-Undangan Yang Dibentuk Di Daerah Oleh Perancang Peraturan PerundangUndangan; Peraturan Menteri Hukum dan Hak Asasi Manusia Nomor 23 Tahun 2018 Tentang Pengharmonisasian Rancangan Peraturan Menteri, Rancangan Peraturan Lembaga Pemerintah Nonkementerian, Atau Rancangan Peraturan Dari Lembaga Nonstruktural Oleh Perancang Peraturan Perundang-Undangan; Peraturan Menteri Hukum dan Hak Asasi Manusia Nomor 31 Tahun 2017 Tentang Perubahan Atas Peraturan Menteri Hukum dan Hak Asasi Manusia Nomor 16 Tahun 2015 Tentang Tata Cara Pengundangan Peraturan Perundang-Undangan Dalam Lembaran Negara Republik Indonesia, Tambahan Lembaran Negara Republik Indonesia, Berita Negara Republik Indonesia, Dan Tambahan Berita Negara Republik Indonesia; dan Peraturan Menteri Hukum dan Hak Asasi Manusia Nomor 2 Tahun 2019 Tentang Penyelesaian Disharmoni Peraturan Perundang-Undangan Melalui Mediasi.

9 Liputan6.Com, " Kementerian ESDM Pangkas 186 Regulasi dan Perizinan, https://www.liputan6.com/bisnis/ read/3347228/kementerian-esdm-pangkas-186-regulasi-dan-perizinan, diakses 20 Januari 2020.

10 CNNIndonesia.Com, "Menko Airlangga Serahkan Draf RUU Omnibus Law Ciptaker ke DPR", https://www. cnnindonesia.com/ekonomi/20200212152021-92-473960/menko-airlangga-serahkan-draf-ruu-omnibuslaw-ciptaker-ke-dpr, diakses 31 Maret 2020.

11 Kompas.id, "UMKM dan Koperasi dalam Omnibus Law RUU Cipta Kerja", https://kompas.id//baca/ riset/2020/02/18/umkm-dan-koperasi-dalam-omnibus-law-ruu-cipta-kerja/, diakses 31 Maret 2020.

12 Hukumonline.Com, "Lima Langkah Penataan Regulasi untuk Pemerintahan Jokowi Jilid II", https://www. hukumonline.com/berita/baca/lt5db95c405cce2/lima-langkah-penataan-regulasi-untuk-pemerintahanjokowi-jilid-ii/, diakses 20 Januari 2020. 
nasional meliputi UU, Peraturan Pemerintah (PP), Peraturan Presiden (Perpres), dan Peraturan Menteri (Permen) yang apabila dirata-rata, 6 regulasi lahir setiap hari di Indonesia. ${ }^{13}$

Sebelum pernyataan Presiden pada 20 Oktober 2019, omnibus law pernah beberapa kali disebut oleh pejabat pemerintahan maupun para akademisi. Tercatat Menteri Agraria dan Tata Ruang/Kepala Badan Pertanahan Nasional Sofyan Djalil pada 15 September 2019 melontarkan ide agar Indonesia mengadopsi prinsip omnibus bill atauomnibus law dalam penyusunan regulasi. ${ }^{14}$ Dengan omnibus law tidak harus merevisi UU satu per satu, Sofyan Djalil mencontohkan ketika ada usulan memperbaiki regulasi di bidang kehutanan maka yang harus direvisi adalah UU No. 41/1999 tentang Kehutanan. Namun, masih ada ganjalan dalam beleid lain semisal UU No. 32/2009 tentang Perlindungan dan Pengelolaan Lingkungan Hidup (PPLH) atau UU No. 5/1960 tentang Peraturan Dasar Pokok-Pokok Agraria. ${ }^{15}$

Akademisi Universitas Indonesia Ima Mayasari melalui opininya 28 November 2018 dengan judul "menggagas omnibus law" menyatakan saat ini Indonesia membutuhkan terobosan yaitu perlunya omnibus law. ${ }^{16}$ Meski Indonesia menganut sistem hukum civil law, sementara omnibus law lahir dari tradisi sistem hukum common law. Namun dalam dunia digital ecosystem dan global governance, tidak ada salahnya Indonesia menerobos ruang batas ini. ${ }^{17}$ Ima juga memberikan contoh negara-negara yang mengadopsi omnibus law seperti Amerika Serikat pada tahun 2009 memperkenalkan The Omnibus Public Land Management Act of 2009, kemudian Filipina telah mulai mereformasi hukum dalam konteks investasi dengan menerbitkan The Omnibus Investment Code. ${ }^{18}$

Terhadap rencana pembentukan omnibus law Maria Farida Indrati guru besar ilmu perundang-undangan Fakultas Hukum Universitas Indonesia dan hakim konstitusi periode 2008-2018 menyampaikan beberapa catatan kritis, pertama, setiap peraturan perundang-undangan harus dibentuk berdasarkan asas-asas pembentukan peraturan perundang-undangan yang patut (beginselen van behoorlijke regelgeving) dan juga berlandaskan landasan filosofis, yuridis, dan sosiologis yang tentunya berbeda bagi setiap peraturan perundangundangan. ${ }^{19}$ Kedua, mengenai eksistensi dari berbagai UU yang beberapa pasalnya dicabut (dipindahkan) dan diletakkan dalam omnibus law, karena setiap UU selain mengatur materi muatan yang berbeda juga mengatur subyek (adressat) yang berbeda-beda. ${ }^{20}$

\section{Ibid.}

14 Bisnis.Com, "UU Tumpang Tindih, Bappenas Usul Indonesia Adopsi Omnibus Law", https://ekonomi.bisnis.com/ $\mathrm{read} / 20160915 / 99 / 584255 / \mathrm{uu}$-tumpang-tindih-bappenas-usul-indonesia-adopsi-omnibus-law, diakses 20 Januari 2020.

15 Ibid.

16 Ima Mayasari, "Menggagas Omnibus Law", https://kumparan.com/dr-ima-mayasari-m-h/menggagas-omnibuslaw-1542018891459839175, diakses 20 Januari 2020.

17 Ibid.

18 Ibid.

19 Maria Farida Indrati, "Omnibus Law", UU Sapu Jagat?, Harian Kompas, 4 Januari 2020, hlm.6

20 Ibid. 
Adanya rencana pembentukan omnibus law di Indonesia serta berbagai respon yang menyertainya maka perlu suatu pengkajian tentang omnibus law untuk mendalami konsep dasar, manfaat, kelemahan, peluang dan tantangan diterapkannya omnibus law dalam sistem perundang-undangan di Indonesia. Melalui pengkajian ini diharapkan adanya suatu pembaruan hukum dalam pembentukan peraturan perundang-undangan dapat dilakukan secara hati -hati dan bijaksana, sehingga tidak menimbulkan gejolak yang justru akan menimbulkan ketidakpastian hukum dalam pelaksanaannya.

Rumusan permasalahan dalam penulisan ini yang akan dijawab adalah, pertama: bagaimana konsepsi, manfaat dan kelemahan pembentukan UU melalui model omnibus law?, kedua: bagaimana peluang dan tantangan omnibus law untuk dapat diadopsi dalam sistem perundang-undangan Indonesia?

\section{B. Metode Penelitian}

Terdapat 2 (dua) pendekatan penelitian hukum terdapat yaitu pendekatan secara normatif dan pendekatan yuridis sosiologis. Pendekatan yuridis normatif pencarian jawaban terhadap terhadap permasalahan dan tujuan penelitian berdasarkan kerangka teori hukum normatif, yang dipergunakan untuk menelaah data adalah teori-teori yang lazim dikenal dalam teori hukum doktrinal, seperti kaidah-kaidah hukum, asas-asas hukum, pengertian-pengertian hukum dan sebagainya. ${ }^{21}$ Sedangkan pendekatan yuridis sosiologis yang bercirikan pada pencarian jawaban terhadap permasalahan dan tujuan penelitian dengan menggunakan teori hukum empiris-sosiologis hukum. ${ }^{22}$ Penulisan ini menggunakan pendekatan penelitian yuridis normatif, dengan pendekatan perundangundangan dan konsep, yang juga mengkaji studi dokumen, yakni menggunakan berbagai data sekunder seperti peraturan perundangundangan, keputusan pengadilan dan teori hukum.

\section{Pembahasan}

\section{Konsepsi, Manfaat Dan Kelemahan Pembentukan UU Melalui Omnibus Law}

\section{a. Konsepsi Omnibus Law}

Tidak ada definisi tunggal mengenai pengertian omnibus law atau omnibus bill, baik itu kamus hukum maupun akademisi hukum memiliki definisi sendiri, namun demikian secara garis besar definisi tersebut memiliki kesamaan. Kamus Hukum Duhaime (The Duhaime Legal Dictionary) mendefinisikan omnibus law sebagai " $A$ draft law before a legislature which contains more than one substantive matter, or several minor matters which have been combined into one bill, ostensibly for the sake of convenience". ${ }^{23}$

Barbara Sinclair mendefinsikan omnibus law sebagai "Legislation That Addresses numerous and not necessarily related subjects, issues, and programs, and therefore is usually highly complex and long, is referred to as

\footnotetext{
21 Soerjono Soekanto, Penelitian Hukum Normatif, Jakarta: Raja Grafindo Persada, 2009, hlm. 56.

22 Ibid.

23 Duhaime.org, Omnibus Bill Definition, http://www.duhaime.org/LegalDictionary/O/OmnibusBill.aspx, diakses 25 Januari 2020.
} 
omnibus legislation". ${ }^{24}$ Apa yang disampaikan Barbara Sinclair lebih menekankan pengertian omnibus law sebagai satu UU yang memuat banyak hal namun belum tentu apa yang dimuat adalah subyek, isu atau program yang saling terkait.

Audrey O'Brien dan Marc Bosc mendefinisikan omnibus law sebagai RUU yang berupaya untuk mengubah, mencabut, atau memberlakukan beberapa ketentuan dalam berbagai UU. ${ }^{25}$ Lebih lanjut menurut Audrey O'Brien melalui omnibus law maka beberapa amandemen UU dilakukan melalui satu UU dalam rangka menfasilitasi satu kebijakan tertentu yang diambil oleh negara. ${ }^{26}$

Herb Gray mengartikan omnibus law sebagai satu UU yang mengubah banyak UU yang berbeda. ${ }^{27}$ Menurut Herb Gray omnibus law didasarkan prinsip adanya satu tujuan yang mengikat semua ketentuan UU yang diusulkan diubah dalam omnibus law ...The essential defence of an omnibus procedure is that the bill in question, although it may seem to create or amend many disparate statutes, in effect has one basic principle or purpose. ${ }^{28}$

Muladi dengan mengutip Gunter menyebutkan bahwa omnibus berasal dari bahasa latin yang mengandung arti 'untuk segalanya', yang dalam hukum dimaknai sebagai perlunya satu dokumen tunggal yang mencakup bersama-sama satu kombinasi subyek yang beraneka ragam atas dasar beberapa kriteria. ${ }^{29}$ Lebih lanjut menurut Muladi omnibus law dapat juga diartikan sebagai sebagai hukum yang mencakup topik yang bermacam-macam dan sering tidak berkaitan satu sama lain (diverse or unrelated) yang harus dikonsolidasikan dan disinkronisasikan. ${ }^{30}$

Maria Farida Indrati memaknai omnibus law sebagai satu UU (baru) yang mengandung atau mengatur berbagai macam substansi dan berbagai macam subyek untuk langkah penyederhanaan dari berbagai UU yang masih berlaku. ${ }^{31}$ Menurut Maria Farida Indrati UU omnibus law tidak tepat jika disamakan dengan UU Payung (raamwet, basiswet, moederwet) yaitu UU yang merupakan induk dari UU lain sehingga kedudukannya lebih tinggi dari UU "anaknya" karena UU Payung inilah yang melimpahkan berbagai pengaturan lebih lanjutnya secara delegasi pada UU lain. ${ }^{32}$

A Ahsin Thohari mengartikan omnibus law sebagai teknik pembentukan UU secara terpadu (omnibus law-making technique). ${ }^{33}$ Teknik ini memungkinkan satu RUU terpadu (omnibus bill) yang berisi perubahan atau bahkan penggantian beberapa UU sekaligus

24 Barbara Sinclair dalam Glen S. Krutz, Hitching a Ride: Omnibus Legislating in the U.S. Congress, ohio state university Press, 2001 p.3.

25 Audrey O'Brien \& Marc Bosc, eds, House of Commons Procedure and Practice, 2nd ed (Cow- ansville, QC: House of Commons \& Éditions Yvon Blais, 2009) at p. 724.

26 Ibid.

27 Herb Gray dalam Adam M Dodek, "Omnibus Bills: Constitutional Constraints and Legislative Liberations", ottawa Law Review • 48:1, p. 12.

28 Ibid.

29 Muladi, "RKUHP Sebagai Omnibus Law", Harian Kompas, 27 November, 2019, hlm $6 .$.

30 Ibid.

31 Maria Farida Indrati, op.cit.

32 Ibid.

33 A Ahsin Thohari, Menakar "Omnibus Law", Koran Sindo, 30 Oktober 2019. 
diajukan ke parlemen untuk mendapatkan persetujuan dalam satu kesempatan pengambilan keputusan. ${ }^{34}$ Apa yang disampaikan oleh A Ahsin Thohari ini ingin membatasi pengertian omnibus law hanya sekedar sebagai teknik pembentukan UU yang menyangkut pilihan metode belaka.

Berdasarkan pengertian berdasarkan kamus hukum maupun akademisi maka dapat diketahui ada perbedaan antara teknik UU biasa yang dipakai Indonesia dengan teknik omnibus law. Beberapa perbedaan tersebut yaitu: Pertama, dari segi substansi yang diatur/dimuat, selama ini kebiasaan UU di Indonesia adalah mengandung satu materi/subyek/substansi tertentu, sementara omnibus law memuat banyak materi/ subyek/substansi yang berbeda dan bahkan dapat tidak saling terkait. Pengertian UU di Indonesia menurut A. Hamid S. Attamimi ialah suatu peraturan yang mengandung isi atau materi tertentu, dan karena itu diperlukan prosedur pembentukan yang tertentu pula (het materiele wetsbegrib). ${ }^{35}$ Menurut Soehino setiap jenis atau bentuk peraturan perundang-undangan itu pasti mengatur suatu materi atau hal keadaan/konkret. Materi apa dan mana yang diatur oleh suatu peraturan itu telah ada ketentuannya. ${ }^{36}$

Mengenai pengertian materi muatan peraturan perundang-undangan menurut $A$. Hamid S. Attamimi adalah isi kandungan atau subtansi yang dimuat dalam UU khususnya dan peraturan perundang-undangan pada umumnya. ${ }^{37}$ Khusus mengenai materi muatan UU menurut Bagir Manan dapat ditentukan berdasarkan tolok ukur umumnya sebagai berikut: 1.ditetapkan dalam Undang-Undang Dasar; 2. ditetapkan dalam UU terdahulu; 3. ditetapkan dalam rangka mencabut, menambah, atau mengganti UU yang lama; 4. materi muatan menyangkut hak dasar atau hak asasi; 5. materi muatan menyangkut kepentingan atau kewajiban rakyat banyak. ${ }^{38}$

Kedua, dari segi teknik pembentukan UU, perubahan atau pencabutan suatu UU yang selama ini lazim dilakukan di Indonesia adalah dengan menggunakan metode satu usulan perubahan UU mengubah atau mencabut satu UU saja serta tidak mengubah substansi UU lain. Sedangkan omnibus law menggunakan teknik mengubah, mencabut, atau memberlakukan beberapa ketentuan dalam berbagai UU hanya melalui satu usulan pembentukan UU kepada Parlemen.

Butir 6 Lampiran II Teknik Penyusunan Peraturan Perundang-undangan UndangUndang Nomor 12 Tahun 2011 tentang Pembentukan Peraturan Perundang-undangan sebagaimana diubah dengan Undang-Undang Nomor 15 Tahun 2019 (UU P3) menyebutkan pada nama peraturan perundang-undangan perubahan ditambahkan frasa perubahan atas di depan judul peraturan perundangundangan yang diubah. Selain itu butir 7 menyebutkan jika peraturan perundang-

34 Ibid.

35 A. Hamid S. Attamimi, Peranan Keputusan Presiden RI dalam Penyelenggaraan Pemerintahan Negara. Disertasi, (Jakarta: Fakultas Pascasarjana Universitas Indonesia,1990), hlm. 198.

36 Soehino, Hukum Tata Negara, Teknik Perundang-undangan,Edisi Kedua, Cet.Keti ga (Yogyakarta: Liberty, 2003), hlm.10..

37 Rosjidi Ranggawidjaja, Pengantar Ilmu Perundang-undangan Indonesia, (Bandung: Mandar Maju, 1998 ), hlm. 53.

38 Bagir Manan, Dasar-dasar PerUndang-Undangan Indonesia, (Jakarta: Ind Hill Co, 1992 ), hlm. 37. 
undangan telah diubah lebih dari 1 kali, di antara kata perubahan dan kata atas disisipkan keterangan yang menunjukkan berapa kali perubahan tersebut telah dilakukan, tanpa merinci perubahan sebelumnya. Untuk pencabutan peraturan perundang-undangan diatur di butir 9 yang menyebutkan pada nama peraturan perundang-undangan pencabutan ditambahkan kata pencabutan di depan judul peraturan perundang- undangan yang dicabut.

Ketiga, di Indonesia dikenal konsep UU kodifikasi, antara omnibus law dengan kodifikasi juga memiliki pengertian yang berbeda. Omnibus law memang menggabungkan atau mengumpulkan ketentuan dari banyak UU, namun ketentuan yang dikumpulkan tersebut topik hukumnya bermacam - macam dan sering tidak berkaitan satu sama lain. Sedangkan Menurut R Soeroso kodifikasi hukum adalah pembukuan hukum dalam suatu himpunan UU dalam materi yang sama. ${ }^{39}$

Kodifikasi menurut Black's Law Dictionary adalah the process of collecting and arranging the laws of a country or state into a code, $t$. e., into a complete system of positive law, scientifically ordered, and promulgated by legislative authority. ${ }^{40}$ Kata kunci pengertian kodifikasi menurut Black Law Dictionary ini adalah adanya tindakan untuk mengumpulkan dan mengatur hukum suatu negara dalam kitab UU yang kemudian diumumkan secara resmi oleh pemegang kuasa pembentukan UU.
Tujuan kodifikasi menurut Satjipto Rahardjo adalah untuk membuat kumpulan peraturan perundang-undangan itu menjadi sederhana dan mudah dikuasai, tersusun secara logis, serasi dan pasti. ${ }^{41}$ Dalam kasus Indonesia contoh kodifikasi adalah hukum pidana dalam Kitab Undang-Undang Hukum Pidana, hukum perdata dalam Kita UndangUndang Hukum Perdata, hukum dagang dalam Kitab Undang-Undang Hukum Dagang.

\section{b. Manfaat Omnibus Law}

Pemilihan penggunaan teknik legislasi dengan model omnibus law oleh para pembentuk UU di berbagai negara memiliki sejumlah alasan. Salah satu alasannya adalah dengan teknik ini maka pembentuk UU akan mudah mencapai kesepakatan atau persetujuan rancangan legislasi baru dan menghindarkan dari kebuntuan politik karena isi dari UU omnibus sangat kompleks dan banyak substansi sehingga perbedaan kepentingan bisa diakomidir dengan masingmasing anggota parlemen dapat memasukkan substansi yang diinginkannya. Sebagaimana dikatakan oleh Louis Massicotte Omnibus bills, when presented in legislatures where members are free to vote as they wish, may include the outcome of complex negotiations between self-interested legislators. ${ }^{42}$

Lebih lanjut Louis Massicotte menjelaskan 2 keuntungan atau manfaat yang didapatkan dari diadopsinya teknis omnibus law dalam pembentukan UU yaitu: Pertama, teknik omnibus law menghemat waktu dan

\footnotetext{
R. Soeroso, Pengantar Ilmu Hukum. Jakarta: Sinar Grafika, 2011, hlm. 77.

40 The Law Dictionary, Featuring Black's Law Dictionary Free Online Legal Dictionary 2nd Ed. What is Codification?, https://thelawdictionary.org/codification/, diakses 26 Januari 2020

41 Satjipto Rahardjo, Ilmu Hukum, Bandung: PT.Citra Aditya Bakti, 1991, hlm. 92.

42 Louis Massicotte, "Omnibus Bills in Theory and Practice", Canadian Parliamentary Review/Spring 2013, p.15.
} 
mempersingkat proses legislasi karena tidak perlu melakukan perubahan terhadap banyak UU yang akan diubah melainkan cukup melalui satu rancangan UU yang berisikan banyak materi perubahan dari berbagai UU. ${ }^{43}$ Dengan hanya melalui satu UU yang berisikan banyak materi perubahan dari berbagai UU maka dapat dihindarkan lamanya perdebatan anggota legislatif terhadap masing-masing UU jika perubahan dilakukan dengan cara biasa. ${ }^{44}$

Kedua, membuat hubungan partai oposisi (minoritas) dan mayoritas di parlemen yang kebiasaannya adalah prinsip menang dan kalah dalam pembahasan rancangan UU, maka dengan omnibus law sama-sama menjadi memiliki kesempatan. ${ }^{45}$ Mengingat materi/ substansi omnibus law sangat banyak maka membuat penolakan terhadap keseluruhan isi suatu UU oleh partai opisisi menjadi terhindarkan karena partai oposisi menjadi memiliki opsi menolak suatu substansi namun di sisi lain menyetujui substansi lainnya. ${ }^{46}$

Adam M. Dodek menyebutkan keuntungan digunakannya teknik omnibus law adalah pembentukan UU menjadi lebih efisien. Hal ini dikarenakan amandemen banyak UU bisa dilakukan hanya melalui satu UU atau UU Tunggal. Selengkapnya Adam M. Dodek menyatakan "Omnibus bills are eficient because they permit the bundling of enactments or amendments to multiple statutes in a single bill. When these relate to the same subject matter, they may facilitate parliamentary consideration of that particular area". ${ }^{47}$

Dalam pandangan Glen S. Krutz omnibus law membawa manfaat dapat mencegah ketidakpastian hukum yang muncul pasca pembentukansatuUUyanghanyamemuat satu materi tertentu akibat potensi pertentangan dengan UU lainnya. ${ }^{48}$ Manfaat lainnya dari penggunaan omnibus law menurut Glen S. Krutz adalah meningkatkan produktivitas dalam pembentukan UU. Argumentasinya adalah ketika tidak ada mayoritas dominan dalam pemerintahan sehingga pengambilan keputusan seringkali mengalami kemacetan akibat perbedaan kepentingan maka teknik omnibus law memungkinkan menjadi solusi karena bisa mengakomodir banyak kepentingan sehingga UU bisa disetujui semua pihak. ${ }^{49}$ Untuk mendukung pendapatnya tersebut Glen S. Krutz melakukan penelitian terhadap pembentukan UU di Kongres AS untuk jangka waktu 1949 - 1994, kesimpulan penelitiannya adalah penggunaan omnibus law oleh Kongres membawa pengaruh independen yang positif dan signifikan terhadap produktivitas legislatif oleh Kongres utamanya di pemerintahan yang kekuatannya terpecah. ${ }^{50}$

A Gluck, A J O'Connell dan R Po menyebutkan bahwa omnibus law meskipun memiliki kerumitan, namun harus diakui dapat mengakomodasi banyak pemangku kepentingan di parlemen (...What unites

\footnotetext{
43 Ibid.

44 Ibid.

45 Ibid.

46 Ibid.

47 Adam M Dodek, op.cit, p. 9.

48 Glen S. Krutz. op.cit, p.141.

49 Ibid.

50 Ibid.
} 
omnibus vehicles in both branches is their length, complexity, and the way in which they often bring together multiple congressional and administrative stakeholders). ${ }^{51}$ Selanjutnya manfaat omnibus law untuk menyatukan berbagai kepentingan di parlemen juga dipertegas Omnibus legislation often comprises "mini-bills"-separate pieces of legislation, or at least separate topics within a single subject, drafted by different committees and linked together. ${ }^{52}$

Manfaat dari omnibus law juga terkait implementasinya yang membuat banyak lembaga akan bertanggung jawab untuk melaksanakannya (...Severalagencies are often jointly responsible for implementing a single piece of very long legislation). ${ }^{53}$ Implementasi bersama ini bisa berupa penerbitan peraturan bersama untuk melaksanakan omnibus law (This joint implementation could be the authority for any one of a number of agencies to issue a rule, the joint issuance of regulations, or the issuance of a rule that has to then be followed by others). ${ }^{54}$

Berdasarkan pandangan dari para akademisi ini, maka terdapat sekurangkurangnya 4 manfaat dari digunakannya teknik legislasi dengan model omnibus law yaitu: (i) mempersingkat proses legislasi dalam hal kebutuhan ingin mengubah banyak ketentuan di berbagai UU dikarenakan tidak perlu melakukan usulan perubahan satu persatu terhadap UU yang ingin diubah; (ii) mencegah kebuntuan dalam pembahasan RUU di Parlemen sebagai akibat banyak substansi yang dimuat dalam omnibus law maka anggota parlemen punya kesempatan untuk melakukan kompromi karena bisa saling bertukar kepentingan; (iii) efisiensi biaya proses legislasi mengingat jika dengan teknik perubahan UU biasa harus menyiapkan biaya untuk perubahan masingmasing UU, sementara jika dengan omnibus law hal demikian tidak diperlukan lagi; dan (iv) harmonisasi pengaturan akan terjaga mengingat perubahan atas banyak ketentuan yang tersebar di berbagai UU dilakukan dalam satu waktu oleh omnibus law.

\section{c. Kelemahan Omnibus Law}

Praktik omnibus law tidak selamanya bebas dari kritik karena dianggap mengandung sejumlah kelemahan. Aaron Wherry menyatakan omnibus law adalah praktik hukum yang pragmatis dan kurang demokratis. Alasannya karena omnibus law mengganti dan mengubah norma beberapa UU yang memiliki inisiatif politik yang berbeda. ${ }^{55}$ Sehingga dengan dikeluarkannya UU omnibus, parlemen atau lembaga legislatif dianggap tidak peka terhadap kompleksitas kepentingan dan aspirasi fraksi-fraksi yang telah menyusun dan mengkompromikan kepentingan-kepentingan dalam UU yang telah dihapus oleh UU omnibus. ${ }^{56}$

\footnotetext{
51 A Gluck, A J O'Connell dan R Po, Unorthodox Lawmaking, Unorthodox Rulemaking, Columbia Law Review Vol. 115: 1789 (2015), p. 1803.

52 Ibid. P. 1804

53 Ibid. P. 1806

54 Ibid.

55 Aaron Wherry dalam Mirza Satria Buana, "Menakar Konsep Omnibus Law Dan Consolidation Law Untuk Harmonisasi Peraturan Perundang-Undangan Indonesia: Pendekatan Perbandingan Hukum Tata Negara", Prosiding Konferensi Nasional Hukum Tata Negara Ke-4 - Penataan Regulasi di Indonesia, Jember, 2017. hlm.312. 56 Ibid.
} 
Dikaitkan dengan teori demokrasi teknik omnibus law mengubah proses deliberatif. ${ }^{57}$ Jumlah rapat dengar pendapat di parlemen saat pembahasan omnibus law secara kuantitas berbeda dengan peyusunan UU dengan cara biasa hal ini dikarenakan omnibus law biasanya dibutuhkan untuk segera diselesaikan karena adanya target tertentu yang harus diselesaikan. Selengkapnya dinyatakan oleh Sinclair dan Smith tentang kelemahan omnibus law: this technique changes the deliberative process. Omnibus bills are often fast-tracked through committees with fewer hearings and less markup consideration than would be expected from several important standard bills. ${ }^{58}$

Kelemahan bahwa muatan omnibus law yang sangat banyak dan topik yang beragam akan mengurangi kehati-hatian dan ketelitian dalam penyusunannya juga diungkapkan Louis Massicotte yaitu when a bill deals with topics as varied as sheries, unemployment insurance and environment, it is unlikely to be examined properly if the whole bill goes to the Standing Commitee on Finance. ${ }^{59}$ the Commonwealth Court of Pennsylvania dalam salah satu putusannya pada 1901 bahkan pernah menyatakan bahayanya penggunaan teknik omnibus law yaitu akibat percampuran antara subyek yang berbeda dan cukup banyak dalam satu UU omnibus juga membawa kebingungan dan gangguan pikiran bagi anggota legislatif karena tak jarang antar subyek tersebut tidak bersesuaian. ${ }^{60}$
Kelemahan bahwa omnibus law membuat parlemen kesulitan memeriksan isi UU dengan benar juga disampaikan Adam M Dodek yaitu ...omnibus bills make it dificult for parliamentarians to properly scrutinize a bill's content and exercise their function in holding the government to account. ${ }^{61}$ Keberadaan omnibus law juga sangat rentan menggerus fungsi parlemen sesungguhnya dalam pembentukan UU, hal ini dikarenakan warga memilih anggota parlemen adalah dalam rangka agar anggota perlemen mempertimbangkan segala sudut pandang dalam pembahasan UU, berdebat dan mencermati isiUU dengan hati-hati, hal mana keinginan konstituen ini sulit terwujud jika perlemen harus membahas dan memeriksa UU omnibus yang isinya mengandung banyak subyek yang tidak terkait. ${ }^{62}$

Omnibus law juga mengandung tantangan hukum dan konstitusi terutama bagi negara yang menganut sistem parlemen yang sepenuhnya menyerahkan kekuasaan membentuk UU di tangan parlemen. Menurut Adam M Dodek dengan omnibus law yang mengandung banyak subyek parlemen menikmati hak istimewa untuk menentukan sendiri isi UU tanpa campur tangan cabang kekuasaan lainnya (The regulation of omnibus bills presents a constitutional and legal challenge, however, because Parliament enjoys the privilege of determining its own processes without interference from the other branches of government). ${ }^{63}$

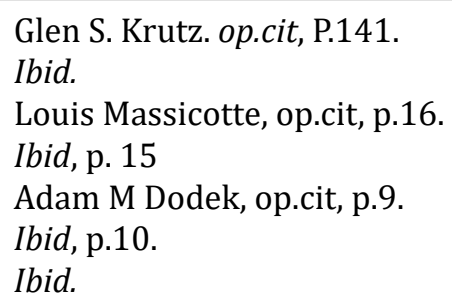


Bagi negara yang mengenal sistem veto seperti Amerika Serikat maka keberadaan omnibus law juga membawa kesulitan bagi Presiden dalam melaksanakan hak veto yaitu menolak satu UU yang disetujui kongres. ${ }^{64}$ Mengingat hak veto Presiden adalah menolak keseluruhan UU maka parlemen menggunakan omnibus law dengan muatannya yang sangat banyak sebagai tameng agar tidak dibatalkan oleh veto Presiden. Beberapa materi muatan yang disukai presiden dimasukkan dalam omnibus law ini sehingga Presiden akan berpikir ulang untuk membatalkan keseluruhan UU. ${ }^{65}$

Dibalik manfaatnya ternyata teknik omnibus law ternyata juga mengandung sejumlah kelemahan. Beberapa kelemahan yang bisa diidentifikasi berdasarkan uraian diatas adalah: (i) pragmatis dan kurang demokratis; (ii) membatasi ruang partisipasi sehingga bertolak belakang dengan demokrasi deliberatif; (iii) mengurangi ketelitian dan kehati-hatian dalam penyusunannya; dan (iv) potensi melampaui ketentuan dalam konstitusi akibat keterbatasan partisipasi dan kurangnya kehati-hatian dalam membahas.

\section{Peluang dan tantangan Adopsi Omnibus Law Dalam Sistem Perundang - Undangan Indonesia}

\section{a. Peluang Adopsi Omnibus Law Dalam Sistem Perundang-undangan Indonesia}

Model pembentukan UU dengan teknik omnibus law jika ditelisik kepada sejarah perundang-undangan Indonesia pernah dilakukan meskipun tidak sama persis. Indonesia pernah memiliki UU Nomor 5 Tahun 1969 tentang Pernyataan Berbagai Penetapan Presiden Dan Peraturan Presiden Sebagai Undang-Undang yang jika dilihat substansinya mengandung ciri sebagai omnibus law karena dalam satu UU ini berisi pernyataan tentang status hukum berbagai produk hukum yang secara substansi mengandung subyek pengaturan berbeda.

UU Nomor 5 Tahun 1969 pada dasarnya adalah tindak lanjut Ketetapan Majelis Permusyawaratan Rakyat Sementara Republik Indonesia Nomor XIX/MPRS/1966 Tahun 1966 Tentang Peninjauan Kembali ProdukProduk Legislatif, Negara Diluar Produk MPRS Yang Tidak Sesuai Dengan UUD 1945. TAP MPRS XIX/1966 ini berisikan peninjauan atas banyak peraturan perundang-undangan yaitu produk-produk legislatif baik yang berbentuk Penetapan-Penetapan Presiden, PeraturanPeraturan Presiden, maupun yang berbentuk Undang-undang dan Peraturan Pemerintah Pengganti Undang-undang.

Substansi UU 5/1969 mengandung tiga klusteryaitu, Pertama, 2 Penetapan-penetapan Presiden dan Peraturan-peraturan Presiden dalam Lampiran I dinyatakan sebagai UU. ${ }^{66}$ Kedua, 36 Penetapan-penetapan Presiden dan Peraturan- peraturan Presiden dalam Lampiran IIA dan IIB dinyatakan sebagai UU dengan ketentuan, bahwa materi Penetapanpenetapan Presiden dan Peraturan-peraturan Presiden tersebut ditampung atau dijadikan

Louis Massicotte, op.cit. p. 15.

Ibid.

66 Penpres 19 Tahun 1963 tentang Pembentukan Mahkamah Militer Luar Biasa, dan Penpres 27 Tahun 1965 tentang Pengeluaran Uang Rupiah Yang Baru Sebagai Alat Pembayaran Yang Sah Bagi Seluruh Wilayah Republik Indonesia Dan Penarikan Uang Rupiah Lama Dari Peredaran. 
bahan bagi penyusunan UU yang baru. ${ }^{67}$ Ketiga, 91 Penetapan-penetapan Presiden dan Peraturan-peraturan Presiden sebagaimana termaksud dalam Lampiran IIIA dan IIIB diserahkan kewenangannya untuk meninjau lebih lanjut dan mengaturnya kembali kepada Pemerintah guna menuangkannya dalam peraturan perundang-undangan atau dijadikan bahan bagi peraturan perundangundangan yang sesuai dengan materi masingmasing. ${ }^{68}$

Contoh berikutnya bahwa pembentukan peraturan perundang-undangan pernah menggunakan teknik omnibus law adalah Ketetapan Majelis Permusyawaratan Rakyat Republik Indonesia Nomor I/MPR/2003 Tentang Peninjauan Terhadap Materi dan Status Hukum Ketetapan Majelis Permusyawaratan Rakyat Sementara dan Ketetapan Majelis Permusyawaratan Rakyat Republik Indonesia Tahun 1960 Sampai Dengan Tahun 2002. Lahirnya TAP MPR I/2003 dilatarbelakangi karena terjadinya perubahan kedudukan, fungsi, tugas, dan wewenang lembaga negara sebagai akibat perubahan UUD 1945 pada 1999 - 2002 mengakibatkan perlunya dilakukan peninjauan terhadap materi dan status hukum Ketetapan Majelis Permusyawaratan Rakyat Sementara dan Ketetapan Majelis Permusyawaratan Rakyat Republik Indonesia. ${ }^{69}$

TAP MPR 1/2003 memuat 6 kluster mengenai status hukum 139 TAP MPRS/MPR pertama, Ketetapan MPRS dan Ketetapan MPR Yang dicabut dan dinyatakan tidak berlaku, ada 8 Ketetapan. Kedua, ketetapan MPRS dan Ketetapan MPR yang dinyatakan tetap berlaku dengan ketentuan, ada 3 Ketetapan. Ketiga, ketetapan MPRS dan Ketetapan MPR yang dinyatakan tetap berlaku sampai dengan terbentuknya pemerintahan hasil pemilu 2004, ada 8 Ketetapan. Keempat, ketetapan MPRS dan Ketetapan MPR yang dinyatakan tetap berlaku sampai dengan terbentuknya UU, ada 11. Kelima, ketetapan MPRS dan Ketetapan MPR yang dinyatakan masih berlaku sampai dengan ditetapkannya Peraturan Tata Tertib baru oleh MPR hasil Pemilu 2004, ada 5 Ketetapan. Keenam, Ketetapan MPRS dan Ketetapan MPR yang dinyatakan tidak perlu dilakukan tindakan hukum lebih lanjut, baik karena bersifat nal (einmalig), telah dicabut, maupun telah selesai dilaksanakan, ada 104 Ketetapan.

Kemudian pada 2017 telah dibentuk UU yang juga seperti omnibus law yaitu UndangUndang Nomor 9 Tahun 2017 Tentang Penetapan Peraturan Pemerintah Pengganti Undang-Undang Nomor 1 Tahun 2017 Tentang Akses Informasi Keuangan Untuk Kepentingan Perpajakan Menjadi Undang-Undang. Perppu 1/2017 yang sudah sah menjadi UU isinya menghapus dan menyatakan tidak berlaku terhadap ketentuan kerahasiaan perbankan, asuransi dan pasar modal terkait akses perpajakan yang sebelumnya diatur dalam UU 7/1992 tentang Perbankan, UU 8/1995 tentang Pasar Modal, UU 32/1997 tentang Perdagangan Berjangka Komoditi, UU 21/2008 tentang Perbankan Syariah. Ciri teknik omnibus law ditunjukkan melalui pengaturan dalam beberapa pasal di UU

\footnotetext{
67 Lampiran IIA berisikan 22 Penpres dan 4 Perpres, Lampiran IIB berisikan 4 Penpres dan 6 Perpres.

68 Lampiran IIIA berisikan 72 Penpres, Lampiran IIIB berisikan 5 Penpres dan 14 Perpres.

69 Konsideran menimbang huruf a dan huruf c TAP MPR I/2003.
} 
yang materinya lintas subyek yang berisi perubahan terhadap ketentuan beberapa UU dan diakhiri keberadaan ketentuan penutup di Pasal 8 yang mencabut ketentuan beberapa pasal dari 5 UU.

Peluang diadopsinya teknik omnibus law secara permanen dalam sistem perundangundangan di Indonesia akan sangat tergantung dari keberhasilan dan manfaat UU omnibus law yang dihasilkan. Hal ini dikarenakan terjadinya transplantasi hukum sangat tergantung dengan gagasan dan kekuatan yang ada dalam hukum itu sendiri. Transplantasi hukum oleh Frederick Schauer didefinisikan sebagai proses dimana hukum dan lembaga hukum dikembangkan di satu negara kemudian di adopsi oleh yang lain (the process by which laws and legal institutions developed in one country are then adopted by another). ${ }^{70}$

Lebih lanjut menurut Schauer untuk dapat terjadinya penyebaran hukum lintas negara sangat tergantung dengan gagasan dan kekuatan yang ada dalam hukum itu sendiri dibandingkan daripada faktor politik dan simbolis. ${ }^{71}$ Hukum yang berkaitan dengan hak individu, identitas nasional dan struktur politik akan kurang dipengaruhi oleh hukum yang berasal dari luar negara dibandingkan keluarga hukum ekonomi, bisnis, sekuritas dan komersial. ${ }^{72}$

\section{b. Tantangan Adopsi Omnibus Law Dalam Sistem Perundang-undangan Indonesia}

Terbuka peluang untuk melakukan Adopsi omnibus law dalam sistem perundangundangan Indonesia, namun demikian peluang ini harus dibarengi dengan kemampuan untuk menjawab tantangan yang muncul. Setidaknya ada 6 tantangan besar bagi adopsi omnibus law di Indonesia yakni: Pertama, permasalahan regulasi Indonesia kompleks bukan hanya soal teknik atau cara penyusunan UU; Kedua, tiap-tiap UU yang ketentuannya diubah oleh omnibus law masing-masing telah memiliki landasan filosofis; Ketiga, prinsip supremasi konstitusi telah meletakkan batasbatas kewenangan mengatur untuk tiap jenis peraturan perundang-undangan; Keempat, ketidakpastian hukum akibat dominasi ego sektoral antar penyelenggara negara; Kelima, parameter menentukan kapan suatu materi harus dengan omnibus law dan kapan dengan UU biasa; dan Keenam, partisipasi publik dalam pembentukan UU di Indonesia dijamin di semua tahapan pembentukan.

PSHK dalam penelitiannya menyebutkan sejumlah permasalahan mendasar terkait perundang-undangan Indonesia yaitu: pertama, tidak sinkronnya perencanaan peraturan perundang-undangan dengan perencanaan dan kebijakan pembangunan; kedua, adanya kecenderungan peraturan perundang-undangan menyimpang dari materi muatan yang seharusnya diatur sehingga muncul"hiper-regulasi"; ketiga, efektivitas peraturan perundang-undangan

\footnotetext{
70 Frederick Schauer, The Politics and Incentives of Legal Transplantation, CID Working Paper Series 2000.44, Harvard University, Cambridge, MA, April 2000. p.1.

$71 \quad$ Ibid, p. 2.

72 Ibid, p. 11.
} 
pada saat implementasi; keempat, tidak adanya prosedur pemantauan dan evaluasi peraturan perundang-undangan; kelima, ketiadaan lembaga khusus yang menangani seluruh aspek dalam sistem peraturan perundang- undangan. ${ }^{73}$

PSHK merekomendasikan sejumlah strategi untuk menyelesaikan sejumlah permaslahan tersebut yaitu pertama, integrasi sistem perencanaan peraturan perundang-undangan dengan perencanaan pembangunan; kedua, pengendalian proses pembentukan peraturan perundang-undangan melalui harmonisasi dan sinkronisasi yang lebih ketat; ketiga, optimalisasi perencanaan legislasi yang lebih terukur dan relevan dengan kebutuhan; keempat, pelembagaan fungsi pemantauan dan evaluasi dalam sistem peraturan perundang-undangan; kelima, pengintegrasian fungsi dalam sistem peraturan perundang-undangan melalui penataan kelembagaan dan penguatan sistem. ${ }^{74}$

Dalam rekomendasinya PSHK sama sekali tidak menyebut teknik omnibus law sebagai salah satu strategi menyelesaikan permasalahan mendasar terkait perundangundangan Indonesia. Hal ini dikarenakan omnibus law adalah upaya perbaikan yang dilakukan berdasarkan komitmen pemerintahan tertentu dan bukan perbaikan sistem sehingga berisiko pada ketidaksinambungan proses perbaikan. ${ }^{75}$

Omnibus law lebih condong sebagai solusi jangka pendek atas permasalahan oleh karena itu pemerintah perlu menerapkan kebijakan yang memastikan proses perbaikan sistem peraturan perundang-undangan berjalan secara sistematis dan berkelanjutan dimana omnibus law tidak memenuhi syarat ini karena tidak disebutkan dalam UUD 1945 maupun UU 12/2011 sehingga keberadaanya hanya melekat pada kebijakan pemerintahan yang bisa tidak dilanjutkan jika terjadi pergantian pemerintahan.

Adopsi omnibus law dalam pembentukan peraturan perundang-undangan di Indonesia memiliki tantangan bagaimana tetap mengakomodir landasan filosofis yang melatarbelakangi lahirnya suatu UU yang hanya mengatur satu subyek tertentu yang kemudian diubah dengan omnibus law yang memuat banyak subyek. Lampiran II butir 19 UU P3 menyebutkan pokok pikiran pada konsiderans UU memuat unsur filosofis, sosiologis, dan yuridis yang menjadi pertimbangan dan alasan pembentukannya yang penulisannya ditempatkan secara berurutan dari filosofis, sosiologis, dan yuridis. Unsur filosofis menggambarkan bahwa peraturan yang dibentuk mempertimbangkan pandangan hidup, kesadaran, dan cita hukum yang meliputi suasana kebatinan serta falsafah bangsa Indonesia yang bersumber dari Pancasila dan Pembukaan UUD 1945.

Maria SW. Sumardjono menyatakan untuk omnibus law RUU Cipta Kerja, UU yang diganti/dicabut untuk diatur ulang ada sekitar 80-an UU dalam berbagai bidang, dengan filosofi serta prinsip dasar/asas-asas

\footnotetext{
73 Pusat Studi Hukum dan Kebijakan (PSHK), Kajian Reformasi Regulasi di Indonesia: Pokok Permasalahan dan Strategi Penanganannya, (Yayasan Studi Hukum dan Kebijakan Indonesia (YSHK)), 2019. hlm.2.

74 Ibid, hlm. 3.

75 Ibid.
} 
masing-masing berbeda sesuai dengan tujuan masing-masing UU. ${ }^{76}$ Untuk itu Maria SW. Sumardjono mempertanyakan Apakah dalam rangka penyederhanaan itu dapat dilakukan "penyimpangan" terhadap filosofi, asas dan konsepsi suatu UU yang diganti/dicabut mengingat sebagai contoh landasan filosofi UU bidang Sumber Daya Alam sama, yaitu Pasal 33 ayat (3) UUD 1945 yang belum tentu dapat tertampung di RUU Cipta Kerja. ${ }^{77}$

Prinsip supremasi konstitusi menghendaki tidak ada muatan peraturan perundangundangan yang melampaui atau bertentangan dengan substansi dalam UUD 1945. Prinsip supremasi konstitusi juga menghendaki kepatuhan penyelenggara negara dan warga masyarakat terhadap putusan Mahkamah Konstitusi (MK) yang oleh UUD 1945 telah diberikan tugas untuk menjaga konstitusi dengan diberikan kewenangan membatalkan UU yang bertentangan dengan UUD 1945. Apabila melihat draft RUU Cipta Kerja yang telah diserahkan ke DPR maka terlihat sejumlah permasalahan terkait ketaatan terhadap prinsip supremasi konstitusi.

Substansi RUU Cipta Kerja memuat 15 Bab, 174 Pasal, 79 UU dengan 1203 Pasal yang terdampak, dari substansi ini ternyata ditemukan ketentuan yang menghidupkan kembali pasal yang telah dibatalkan oleh MK yaitu Pasal 251 Undang-Undang Nomor 23
Tahun 2014 tentang Pemerintahan Daerah yang mengatur Peraturan Daerah yang bertentangan dengan ketentuan peraturan perundang- undangan yang lebih tinggi dapat dicabut dan dinyatakan tidak berlaku dengan Peraturan Presiden. ${ }^{78}$ Kemudian melampaui ketentuan UUD 1945 melalui ketentuan Pasal 170 yang memberikan wewenang PP bisa mengubah ketentuan UU yaitu dalam rangka percepatan pelaksanaan kebijakan strategis cipta kerja Pemerintah Pusat berwenang mengubah ketentuan dalam UU ini dan/atau mengubah ketentuan dalam UU yang tidak diubah dalam UU ini dengan PP.

Penggunaan teknik seperti omnibus law pernah dipraktikkan dalam pembentukan peraturan perundang-undangan di Indonesia, namun keengganan pihak terkait utamanya di antara penyelenggara negara untuk mengikutinya telah membawa kesulitan utamanya justru menciptakan ketidakpastian hukum. Maria Farida Indrati memberikan contoh bagaimana pembentukan UU dengan teknik omnibus law tidak serta merta akan memberikan kepastian hukum pasca pengundangannya sebagaimana terjadi dalam pengaturan tentang Dewan Perwakilan Rakyat Daerah (DPRD) yang sebelumnya ada di UU Nomor 17 Tahun 2014 tentang MPR, DPR, DPD dan DPRD kemudian dicabut oleh UU 23/2014 tentang Pemerintahan Daerah. ${ }^{79}$ UU 23/2014

76 Maria SW. Sumardjono, "Mendorong Investasi Dalam Disharmoni Pengaturan Sumber Daya Alam (SDA) di Indonesia", Presentasi pada seminar, Menyikapi Omnibus Law: Pro Kontra RUU Cipta Lapangan Kerja, diselenggarakan oleh Djokosoetono Research Center dan Bidang Studi Hukum Administrasi Negara Universitas Indonesia, Depok 6 Februari 2020.

77 Ibid.

78 Putusan MK yang membatalkan kewenangan Pembatalan Perda oleh Eksekutif adalah Putusan MK Nomor 137/ PUU-XIII/2015 dan Nomor 56/PUU-XIV/2016.

79 Maria Farida Indrati, "Menyikapi Omnibus Law Sebagai UU Sapu Jagad", Presentasi pada seminar, Menyikapi Omnibus Law: Pro Kontra RUU Cipta Lapangan Kerja, diselenggarakan oleh Djokosoetono Research Center dan Bidang Studi Hukum Administrasi Negara Universitas Indonesia, Depok 6 Februari 2020. 
telah mengubah dan mencabut Pasal 1 angka 4, Pasal 314 sampai dengan Pasal 412, Pasal 418 sampai dengan Pasal 421 UU 17/2014, namun dalam kenyataannya sampai dengan Perubahan ketiga terhadap UU 17/2014 ( 30 September 2019) keseluruhan Pasal-pasal tersebut tetap berlaku dan tidak diubah atau dicabut. ${ }^{80}$

Mengingat kenyataan bahwa teknik omnibus law tidak serta merta akan menghasilkan kepastian hukum maka Maria Farida Indrati menyatakan di adopsi nya omnibus law harus disertai sejumlah pemenuhan persyaratan. ${ }^{81}$ Argumentasinya adalah dikarenakan selama ini pembentukan peraturan perundang-undangan Indonesia mempunyai ciri yaitu berdasarkan tradisi civil law (eropa kontinental), keterikatan pada sumber hukum tertinggi yaitu Pancasila dan UUD 1945, Pasal 1 ayat (3) UUD 1945 negara Indonesia adalah negara hukum, dan UU P3. ${ }^{82}$

Sampai saat ini belum ada parameter jelas untuk menentukan tema kebijakan apakah yang harus dibuat dengan teknik omnibus law dan mana yang harus dengan UU biasa. Pada dasarnya teknik omnibus law sebaiknya dihindari untuk topik atau tema kebijakan yang mengandung skala besar utamanya berkaitan dengan Hak Asasi Manusia, melainkan sebaiknya dibatasi untuk skala menengah. Untuk UU skala besar yang berkaitan dengan Hak Asasi Manusia sebaiknya tetap dengan teknik pembentukan UU Biasa sebagaimana dikatakan Glen S. Krutz
Omnibus bills are probably most useful for midlevel policy change. Legislative proposals for large-scale changes are more likely to have to go it alone. ${ }^{83}$ Menggunakan teknis omnibus law secara permanen dalam pembentukan UU juga sebaiknya tidak dilakukan karena untuk pembahasan UU strategis berdampak luas butuh pembahasan dan pemberian pertimbangan yang mendalam. ${ }^{84}$

Beberapa negara yang telah lama mengadopsi omnibus law seperti Amerika Serikat juga menyadari tentang pentingnya tidak harus selalu menggunakan omnibus law melainkan kembali kepada konsep UU hanya mengatur satu subyek dalam pembahasannya. Di Amerika Serikat sendiri, kurang lebih 42 negara bagiannya melalui konstitusi negara-negara bagiannya sudah banyak yang mengatur tentang satu subyek dalam satu UU (The One Subject at a Time Act). ${ }^{85}$ Semisal Konstitusi Negara Bagian California yang menyatakan: "a statute shall embrace but one subject, which shall be expressed by its title. If a statute embraces a subject not expressed in its title, only the part not expressed is void". ${ }^{86}$

Berkaitan dengan pembentukan peraturan perundang-undangan asas pembentukan peraturan perundang-undangan yang baik sangat penting untuk diperhatikan mengingat berfungsi sebagai pondasi dari sistem hukum positif dan sebagai batu uji kritis terhadap sistem hukum positif serta sebagai pedoman atau suatu rambu-rambu dalam pembentukan peraturan perundang-

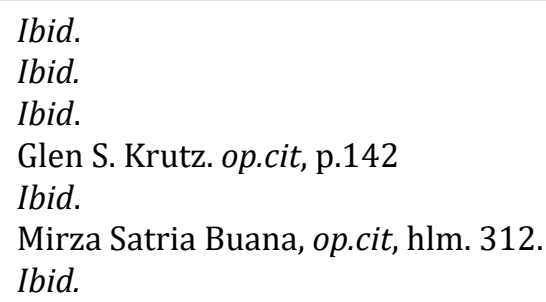


undangan yang baik. ${ }^{87}$ Pasal 5 huruf g UU P3 mengatur Dalam membentuk Peraturan Perundang-undangan harus dilakukan berdasarkan pada asas Pembentukan Peraturan Perundang-undangan yang baik, yang meliputi:... keterbukaan. Pasal 88 UU P3 juga mengatur kewajiban Penyebarluasan Naskah Akademik dan RUU bukan hanya saat naskah diserahkan ke DPR namun seharusnya sejak penyusunan Prolegnas, penyusunan RUU, pembahasan RUU, hingga Pengundangan UU. Penyebarluasan naskah ini merupakan sarana agar masyarakat dapat memberikan masukan secara lisan dan/ atau tertulis dalam Pembentukan Peraturan Perundang-undangan sebagaimana dijamin Pasal 96 UU P3.

Omnibus law dapat diadopsi di Indonesia sepanjang memperhatikan asas keterbukaan dan kewajiban penyebarluasan naskah dalam rangka menjamin partisipasi publik. Kaitannya dengan RUU Cipta kerja sejak awal banyak pihak menginginkan dibahas secara transparan dengan memperhatikan masukan dari pihak-pihak yang mempunyai hubungan dengan RUU tersebut. Komisi Nasional Hak Asasi Manusia (Komnas HAM) mengkritik proses penyusunan Omnibus Law tidak akuntabel dan partisipatif. Lebih lanjut Komnas HAM menyatakan bahwa omnibus law harus terbuka karena jika tidak terbuka atas RUU Omnibus Law ini, maka akan terjadi pelanggaran konstitusi yakni tidak akuntabel dan partisipatif karena keterbukaan dan partisipasi adalah pilar konstitusi. ${ }^{88}$
Jaminan partisipasi publik dalam pembentukan omnibus law merupakan salah satu syarat yang tidak bisa ditawar bagi diadopsinya omnibus law di Indonesia. sebagaimana disampaikan Maria Farida Indrati tentang sejumlah persyaratan yang harus dipenuhi apabila omnibus law diadopsi dalam sistem perundang-undangan di Indonesia yaitu: Pertama, adanya pemenuhan azas keterbukaan, kehati-hatian, dan partisipasi masyarakat; Kedua, diperlukan sosialisasi yang luas, terutama bagi pejabat dan pihak yang terkait dalam substansi RUU nya, kalangan profesi hukum, dan akademisi; Ketiga, pembahasan di DPR yang transparan dengan memperhatikan masukan dari pihakpihak yang mempunyai hubungan dengan RUU, dan tidak tergesa-gesa pembahasannya; Keempat, mempertimbangkan jangka waktu yang efektif berlakunya UU tersebut; dan Kelima, mempertimbangkan keberlakuan UU yang terdampak (existing). ${ }^{89}$

\section{Penutup}

Terdapat perbedaan antara teknik UU biasa yang dipakai di Indonesia dengan omnibus law yaitu dari segi substansi yang diatur/dimuat, metode perubahan UU, dan di Indonesia dikenal konsep UU Kodifikasi, yang mana omnibus law dengan kodifikasi memiliki pengertian yang berbeda. Terdapat sekurang-kurangnya 4 manfaat teknik legislasi model omnibus law yaitu: (i) mempersingkat pelaksanaan proses legislasi; (ii) mencegah kebuntuan dalam pembahasan RUU di

A Hamid S Attamimi, op.cit, hlm. 300.

88 Komnas HAM.go.id, "Komnas HAM: Penyusunan Omnibus Law Tidak Akuntabel dan Partisipatif", https:// www.komnasham.go.id/index.php/news/2020/1/31/1319/komnas-ham-penyusunan-omnibus-law-tidakakuntabel-dan-partisipatif.html, diakses 5 Februari, 2020.

89 Ibid. 
Parlemen; (iii) efisiensi biaya proses legislasi; dan (iv) harmonisasi pengaturan akan terjaga. Dibalik manfaatnya teknik omnibus law ternyata mengandung kelemahan mulai dari pragmatis dan kurang demokratis, membatasi ruang partisipasi sehingga bertolak belakang dengan demokrasi deliberatif, mengurangi ketelitian dan kehati-hatian dalam penyusunannya hingga berpotensi melampaui ketentuan dalam konstitusi akibat keterbatasan partisipasi dan kurangnya kehati-hatian dalam membahas.

Terbuka peluang adopsi teknik omnibus law dalam Pembentukan UU di Indonesia mengingat pembentukan dengan teknik omnibus law sebelumnya pernah dilakukan meskipun tidak sama persis yaitu UU 5/1969 tentang Pernyataan Berbagai Penetapan Presiden dan Peraturan Presiden Sebagai UU, dan UU 9/2017 Tentang Penetapan Perppu 1/2017 Tentang Akses Informasi Keuangan Untuk Kepentingan Perpajakan Menjadi UU. Disamping peluang setidaknya ada 6 (enam) tantangan besar bagi adopsi omnibus law di Indonesia yakni: (i) permasalahan regulasi Indonesia kompleks; (ii) tiap-tiap UU yang ketentuannya diubah oleh omnibus law telah memiliki landasan filosofis; (iii) prinsip supremasi konstitusi meletakkan batas-batas kewenangan mengatur tiap jenis peraturan perundang-undangan; (iv) ketidakpastian hukum akibat dominasi ego sektoral antar penyelenggara negara; (v) parameter menentukan kapan suatu materi harus dengan omnibus law dan kapan dengan UU biasa; dan (vi) partisipasi publik dalam pembentukan UU telah dijamin di semua tahapan pembentukan.

Sejumlah persyaratan yang harus dipenuhi apabila omnibus law diadopsi dalam sistem perundang-undangan di Indonesia yaitu adanya pemenuhan azas keterbukaan dan partisipasi masyarakat sejak tahap penyusunan, saat pembahasan di DPR harus dilakukan secara transparan, hati-hati dan tidak tergesa-gesa, berikutnya substansinya harus dipastikan tidak melampaui konstitusi dan tetap mengakomodir aspek filosofis dari berbagai UU yang diubah. Patut jadi perhatian bahwa permasalahan regulasi di Indonesia tidak bisa diselesaikan hanya dengan teknik omnibus law melainkan pemerintah perlu mengadopsi kebijakan yang memastikan proses perbaikan sistem peraturan perundangundangan berjalan secara sistematis dan berkelanjutan salah satunya membentuk lembaga khusus yang menyatukan berbagai fungsi dalam pembentukan peraturan perundang-undangan.

\section{Daftar Pustaka}

\section{Buku}

Attamimi, A. Hamid S, Peranan Keputusan Presiden RI dalam Penyelenggaraan Pemerintahan Negara. Disertasi (Jakarta: Fakultas Pascasarjana Universitas Indonesia, 1990)

Krutz, Glen dalam Barbara Sinclair, SHitching a Ride: Omnibus Legislating in the U.S. Congress (Ohio State University Press, 2001)

Manan, Bagir, Dasar-dasar PerUndang-Undangan Indonesia (Jakarta: Ind Hill Co, 1992)

O’Brien, Audrey \& Marc Bosc, eds, House of Commons Procedure and Practice, 2nd ed (Cow- ansville, QC: House of Commons \& Éditions Yvon Blais, 2009)

Pusat Studi Hukum dan Kebijakan (PSHK), Kajian Reformasi Regulasi di Indonesia: Pokok Permasalahan dan Strategi Penanganannya, (Yayasan Studi Hukum dan Kebijakan Indonesia (YSHK), 2019)

Rahardjo, Satjipto, Ilmu Hukum (Bandung: PT.Citra Aditya Bakti, 1991) 
Ranggawidjaja, Rosjidi, Pengantar IImu Perundang-undangan Indonesia, (Bandung: Mandar Maju, 1998)

Soehino, Hukum Tata Negara, Teknik Perundangundangan, Edisi Kedua, Cet.Keti ga (Yogyakarta: Liberty, 2003), hlm.10

Soekanto, Soerjono Penelitian Hukum Normatif (Jakarta: Raja Grafindo Persada, 2009)

Soeroso, R. Pengantar Ilmu Hukum (Jakarta: Sinar Grafika, 2011)

\section{Makalah/Artikel/Prosiding/Hasil Penelitian}

A Gluck, A J O'Connell dan R Po, Unorthodox Lawmaking, Unorthodox Rulemaking, Columbia Law Review Vol. 115: 1789 (2015)

Buana, Mirza Satria, "Menakar Konsep Omnibus Law Dan Consolidation Law Untuk Harmonisasi Peraturan Perundang-Undangan Indonesia: Pendekatan Perbandingan Hukum Tata Negara", Prosiding Konferensi Nasional Hukum Tata Negara Ke-4 - Penataan Regulasi di Indonesia, Jember, 2017. hlm.312

Indrati S, Maria Farida, "Menyikapi Omnibus Law Sebagai UU Sapu Jagad", Presentasi pada seminar, Menyikapi Omnibus Law: Pro Kontra RUU Cipta Lapangan Kerja, diselenggarakan oleh Djokosoetono Research Center dan Bidang Studi Hukum Administrasi Negara Universitas Indonesia, Depok 6 Februari 2020 Indrati, Maria Farida, "Omnibus Law", UU Sapu Jagat?, Harian Kompas, 4 Januari 2020, hlm.6

Massicotte, Louis, "Omnibus Bills in Theory and Practice", Canadian Parliamentary Review/ Spring 2013

M. Dodek, Adam, "Omnibus Bills: Constitutional Constraints and Legislative Liberations", Ottawa Law Review • 48:1

Muladi, "RKUHP Sebagai Omnibus Law", Harian Kompas, 27 November, 2019, hIm 6.

Schauer, Frederick, The Politics and Incentives of Legal Transplantation, CID Working Paper Series 2000.44, Harvard University, Cambridge, MA, April 2004

Sumardjono, Maria SW, "Mendorong Investasi Dalam Disharmoni Pengaturan Sumber Daya Alam (SDA) di Indonesia", Presentasi pada seminar, Menyikapi Omnibus Law: Pro Kontra RUU Cipta Lapangan Kerja, diselenggarakan oleh Djokosoetono Research Center dan Bidang Studi Hukum Administrasi Negara Universitas Indonesia, Depok 6 Februari 2020
Thohari, A Ahsin, Menakar "Omnibus Law", Koran Sindo, 30 Oktober 2019

\section{Peraturan}

Peraturan Presiden Nomor 44 Tahun 2015 Tentang Kementerian Hukum Dan Hak Asasi Manusia

Penpres 19 Tahun 1963 tentang Pembentukan Mahkamah Militer Luar Biasa, dan Penpres 27 Tahun 1965 tentang Pengeluaran Uang Rupiah Yang Baru Sebagai Alat Pembayaran Yang Sah Bagi Seluruh Wilayah Republik Indonesia Dan Penarikan Uang Rupiah Lama Dari Peredaran.

Peraturan Menteri Hukum Dan Hak Asasi Manusia Nomor 22 Tahun 2018 Tentang Pengharmonisasian Rancangan Peraturan Perundang-Undangan Yang Dibentuk Di Daerah Oleh Perancang Peraturan PerundangUndangan

Peraturan Menteri Hukum Dan Hak Asasi Manusia Nomor 23 Tahun 2018 Tentang Pengharmonisasian Rancangan Peraturan Menteri, Rancangan Peraturan Lembaga Pemerintah Nonkementerian, Atau Rancangan Peraturan Dari Lembaga Nonstruktural Oleh Perancang Peraturan Perundang-Undangan

Peraturan Menteri Hukum Dan Hak Asasi Manusia Nomor 31 Tahun 2017 Tentang Perubahan Atas Peraturan Menteri Hukum Dan Hak Asasi Manusia Nomor 16 Tahun 2015 Tentang Tata Cara Pengundangan Peraturan PerundangUndangan Dalam Lembaran Negara Republik Indonesia, Tambahan Lembaran Negara Republik Indonesia, Berita Negara Republik Indonesia, Dan Tambahan Berita Negara Republik Indonesia;

Peraturan Menteri Hukum Dan Hak Asasi Manusia Nomor 2 Tahun 2019 Tentang Penyelesaian Disharmoni Peraturan Perundang-Undangan Melalui Mediasi.

Undang-Undang Dasar Negara Republik Indonesia Tahun 1945 (UUD 1945)

Undang-Undang Nomor 12 Tahun 2011 tentang Pembentukan Peraturan Perundangundangan.

\section{Internet}

Bisnis.com, "UU Tumpang Tindih, Bappenas Usul Indonesia Adopsi Omnibus Law", https://ekonomi.bisnis.com/ read/20160915/99/584255/uu-tumpang- 
tindih-bappenas-usul-indonesia-adopsiomnibus-law, diakses 20 Januari 2020

CNNIndonesia.com, "Menko Airlangga Serahkan Draf RUU Omnibus Law Ciptaker ke DPR", https://www.cnnindonesia.com/ ekonomi/20200212152021-92-473960/ menko-airlangga-serahkan-draf-ruu-omnibuslaw-ciptaker-ke-dpr, diakses 31 Maret 2020

Duhaime.org, Omnibus Bill Definition, http://www. duhaime.org/LegalDictionary/O/OmnibusBill. aspx, diakses 25 Januari 2020

Hukumonline.com, "Ini 3 Agenda Paket Reformasi Hukum Jilid II", https://www.hukumonline. com/berita/baca/lt587e0fdb06ea8/ini-3agenda-paket-reformasi-hukum-jilid-ii/, diakses 18 Januari 2020

Hukumonline.com, "Lima Langkah Penataan Regulasi untuk Pemerintahan Jokowi Jilid II", https://www.hukumonline.com/berita/baca/ It5db95c405cce2/lima-langkah-penataanregulasi-untuk-pemerintahan-jokowi-jilid-ii/, diakses 20 Januari 2020

Ima Mayasari, "Menggagas Omnibus Law", $\quad$ https://kumparan.com/dr-imamayasari-m-h/menggagas-omnibuslaw-1542018891459839175, diakses 20 Januari 2020

Komnas HAM.go.id, "Komnas HAM: Penyusunan Omnibus Law Tidak Akuntabel dan Partisipatif", https://www.komnasham.go.id/index. $\mathrm{php} /$ news/2020/1/31/1319/komnas-hampenyusunan-omnibus-law-tidak-akuntabeldan-partisipatif.html, diakses 5 Februari, 2020
Kompas.Com. "Naskah Lengkap Pidato Presiden JokoWidodo dalam Pelantikan Periode 2019-2024", https://nasional. kompas.com/jeo/naskah-lengkap-pidatopresiden-joko-widodo-dalam-pelantikanperiode-2019-2024, diakses 18 Januari 2020

Kompas.id, "UMKM dan Koperasi dalam Omnibus Law RUU Cipta Kerja", https://kompas.id// baca/riset/2020/02/18/umkm-dan-koperasidalam-omnibus-law-ruu-cipta-kerja/, diakses 31 Maret 2020

Liputan6.Com, " Kementerian ESDM Pangkas 186 Regulasi dan Perizinan, https://www.liputan6. $\mathrm{com} / \mathrm{bisnis} / \mathrm{read} / 3347228 /$ kementerianesdm-pangkas-186-regulasi-dan-perizinan, diakses 20 Januari 2020

Sekretariat Negara. go.id, "RUU Omnibus Law: Upaya Perkuat Perekonomian Nasional",https://www.setneg.go.id/baca/ index/ruu_omnibus_law_upaya_perkuat_ perekonomian_nasional, diakses 2 Februari 2020

Sekretariat Kabinet.Go.Id, "Buat Pemerintah Tidak Leluasa, Presiden Jokowi Minta Aturan-Aturan Disederhanakan", https://setkab.go.id/buatpemerintah-tidak-leluasa-presiden-jokowiminta-aturan-aturan-disederhanakan/, diakses 18 Januari 2020

The Law Dictionary, Featuring Black's Law Dictionary Free Online Legal Dictionary 2nd Ed.Top of Form Bottom of Form What is Codification?, https://thelawdictionary.org/ codification/, diakses 26 Januari 2020 